\title{
THE REACTION OF STOCK MARKETS IN THE GULF COOPERATION COUNCIL COUNTRIES TO ECONOMIC POLICY UNCERTAINTY IN THE UNITED STATES
}

\author{
Abdullah Saeed S ALQAHTANI ${ }^{1}$, Hongbing OUYANG ${ }^{2}$, Adam ALI ${ }^{3}$ \\ ${ }^{1-3}$ Huazhong University of Science and Technology, Wuhan, China \\ Corresponding author's e-mail: e20162019@gmail.com
}

\begin{abstract}
This study investigates if the changes in economic policy uncertainty in the U.S. can explain the returns on stock markets of Bahrain, Kuwait, Oman, Qatar, Saudi Arabia and the United Arab Emirates. The study also examines how the stock market returns of the six GCC countries respond to the changes in economic policy uncertainty in the U.S. The results demonstrate that changes in economic policy uncertainty in the U.S. are not significantly linked with the returns on all the stock markets except Oman stock market, which shows a statistical significant negative relationship with the changes in economic policy uncertainty in the U.S. Controlling for the effects of the U.S. stock market and oil price, returns on all the six GCC markets including Oman show insignificant coefficients. The returns on all the stock markets do not respond to the changes in economic policy uncertainty. The results of Granger causality tests show that the changes in economic policy uncertainty in the U.S. do not cause the returns of all the six GCC stock markets.
\end{abstract}

Keywords: GCC, Oil Markets, Policy Uncertainty Index, Stock Market Performance, Spillover Effects, USA.

JEL Classification: E60, F40, G12, G15

\section{INTRODUCTION}

By the beginning of the 1980s, six countries in Arabian Peninsula decided to form strong alliance in order to overcome economic and social difficulties they were facing. At that time, Bahrain, Kuwait, Oman, Qatar, Saudi Arabia and the United Arab Emirates formed regional intergovernmental political and economic union consisting of all Arab States of the Persian Gulf. This institution is called the Gulf Cooperation Council (GCC). In 1998, total intra-trade by the GCC countries was about $\$ 8$ billion; while in 2017 it was $\$ 175$ billion (World Bank, 2010; European Commission, 2018). Right from the beginning the USA has recognized the GCC as an important economic partner. By 1998, total trade between the GCC and the USA was $\$ 30$ billion, while in 2017 it reached $\$ 72$ billion (Anthony, 1999; European Commission, 2018). Since trade between the US and the GCC increased significantly, they were all open not just for new business opportunities, but also for spillovers. The financial crisis of 2007-2008 and the 2010s oil gluts produced 
numerous effects on the economies of the USA and GCC, which in the end slowed down the increase in trade.

When it comes to spillover effects, they usually start with existence of uncertainty among analysed subjects. Bernanke (1983) sees uncertainty as a huge problem for companies that are forced to delay investments when the costs of planned projects face unpredicted volatility. This volatility eventually goes from micro to macro level, which can cause spillover effects around the world. Some authors point out that other reasons for the existence of economic uncertainty are precautionary spending cutbacks by households, upward pressure on the cost of finance, managerial risk - aversions and interactions between nominal rigidities and search frictions (Panousi \& Papanikolaou, 2012; Pastor \& Veronesi, 2013; Gilchrist, Sim \& Zakrajšek, 2014; Basu \& Bundick, 2014; Leduc \& Liu, 2015). On the other hand, there are studies that emphasise detrimental economic effects of monetary, fiscal and regulatory policy uncertainty (Friedman, 1968; Rodrik, 1991; Higgs, 1997; Hassett \& Metcalf, 1999). Pastor and Veronesi (2012) developed a model that helped in understanding the connection between market fluctuations, policy uncertainty and stock market volatility in order for policymakers to better prepare for potential shocks. Born and Pfeifer (2014), also Fernandez-Villaverde et al. (2015) studied multi-factored policy uncertainty by using the DSGE models. They found the existence of moderately negative effects.

Due to economic shocks that hit numerous countries at the same time, many authors have started to pay more attention to international spillovers. With the reduced form of GARCH models, a group of authors detected some spillovers from the U.S. to Japan and the UK equity markets, both for returns and in particular for conditional volatility (Hamao, Masulis \& Ng, 1990; King, Sentana \& Wadhwani, 1994; Lin, Engle \& Ito, 1994). Becker, Finnerty and Friedman (1995) found that US news and information were responsible for the existence of spillovers between the U.S. and UK stock markets. Ehrmann and Fratzscher (2004) confirmed that news and information could have strong impact on changing conditions in some markets, but these spillovers were much stronger from the U.S. to Euro market than in the opposite direction. Since the U.S. has strong and well-established financial markets, it is not unusual that many well-known global spillovers have originated in the U.S. (Goldberg \& Leonard, 2003; Bayoumi \& Swiston, 2007; Ehrmann \& Fratzscher, 2009; Kim, Salem \& Wu, 2015; Fratzscher, Lo Duca \& Straub, 2018).

At the regional level, customs, monetary and economic unions are very exposed to spillovers between member countries. Fadejeva, Feldkircher and Reininger (2017) indicated that the emerging European economies are the most vulnerable economies to all shocks either from the U.S. or euro zone. Spillover effects are sometimes larger than domestic response which is why developing economies are struggling to overcome external economic shocks. Sum (2012) empirically proved that changes in the European economic policy uncertainty have negative effects on stock markets in the European Union, Norway, Russia, Switzerland, Turkey and Ukraine. Beirne et al. (2010) examined global and regional spillovers for 41 emerging economies in Asia, Europe, Latin America and the Middle East. They found that global spillovers had a stronger impact on the economies in Asia and Europe, while regional spillovers produced a more significant effect than global 
spillovers in Latin America and the Middle East. Sugimoto, Matsuki and Yoshida (2014) analysed spillovers in Africa during the U.S. financial crisis and the European sovereign debt crisis. The study found the existence of strong and negative relationship between global spillovers and African stock markets. As for regional spillovers, their impact in Africa does not produce significant effects. Another study showed that the South African regional market was the most influential in propagating shocks to other African markets (Boako \& Alagidede, 2018). Several studies found the existence of strong and statistically significant impact of spillover effects among the regions in China and Spain (Johansson \& Ljungwall, 2009; Zhou, Zhang \& Zhang, 2012; Ouyang \& Fu, 2012; Marquez, Ramajo \& Hewings, 2015; Marquez-Ramos, 2016).

This study investigates the effect of changes in economic policy uncertainty in the U.S. on the returns of stock markets in Bahrain, Kuwait, Oman, Qatar, Saudi Arabia and the United Arab Emirates. The study also examines how stock market returns of the six GCC countries respond to changes in economic policy uncertainty in the U.S. The Granger causality test is carried out to know if changes in economic policy uncertainty in the U.S. cause returns of the GCC stock markets. This study will help in providing a better understanding of the GCC country financial markets and their relationship with the U.S.

\section{METHODOLOGY AND DATA}

In order to conduct research, appropriate data should be collected. The study used monthly data on economic policy uncertainty (EPU) in the U.S. and GCC stock market indices from 2004:7 to 2018:8. The monthly data on economic policy uncertainty in the U.S. were collected from the Economic Policy Uncertainty Index website at http://www.policyuncertainty.com. The monthly data on stock markets of the GCC countries, stock market of the United States (S\$P500) and oil price (Brent) were obtained from Bloomberg.

Hypothesis that will be tested in this paper is: $\mathrm{H} 1$ : Changes in economic policy in the U.S. have negative impacts on the stock markets of the GCC countries. First, descriptive statistics and correlation analysis are carried out. After that, time-series regression analysis is implemented. Time-series regression will help us understand the impacts of economic policy uncertainty in the U.S. on each of the GCC countries. In this case, economic policy uncertainty in the U.S. is an independent variable, while stock market prices of each individual GCC country is a dependent variable as shown in (equation 1). To control for the effects of U.S. stock market and oil price, returns on S\&P500 and Brent are included in time-series regression analysis. Vector autoregressive (VAR) model is employed to know how returns on each GCC country respond to a shock in economic policy uncertainty in the U.S. Implementing all these steps will help us understand the ways in which GCC countries are exposed to economic shocks in the U.S. and how they behave under these circumstances.

$$
\begin{gathered}
R_{i t}=\alpha+\beta \Delta E P U_{i t}+\varepsilon_{i t}, \\
R_{i t}=\alpha+\beta \Delta E P U_{i t}+\gamma S P_{i t}+\delta B R E_{i t}+\varepsilon_{i t}
\end{gathered}
$$




$$
\left(\begin{array}{c}
R_{t}=\alpha+\sum_{i=1}^{p} \lambda_{i} R_{t-i}+\sum_{i=1}^{p} \varphi_{i} S P_{t-i}+\sum_{i=1}^{p} o_{i} B R E_{t-i}+\sum_{i=1}^{p} \lambda_{i} \Delta E P U_{t-i}+\varepsilon_{t} \\
S P_{t}=\tau+\sum_{i=1}^{p} \delta_{i} R_{t-i}+\sum_{i=1}^{p} \phi_{i} S P_{t-i}+\sum_{i=1}^{p} \dot{o}_{i} B R E_{t-i}+\sum_{i=1}^{p} \psi_{i} \Delta E P U_{t-i}+\eta_{t} \\
B R E_{t}=v+\sum_{i=1}^{p} \rho_{i} R_{t-i}+\sum_{i=1}^{p} S_{i} S P_{t-i}+\sum_{i=1}^{p} o_{i} B R E_{t-i}+\sum_{i=1}^{p} \dot{v}_{i} \Delta E P U_{t-i}+\chi_{t} \\
\Delta E P U_{t}=\rho+\sum_{i=1}^{p} \pi_{i} R_{t-i}+\sum_{i=1}^{p} \theta_{i} S P_{t-i}+\sum_{i=1}^{p} \zeta_{i} B R E_{t-i}+\sum_{i=1}^{p} \iota_{i} \Delta E P U_{t-1}+\mu_{t}
\end{array}\right),
$$

where $R_{t}$ is return on a country's stock market index in month $t ; R_{t-i}$ is return on a country's stock market index in month $t-i$; SPt is return on the S\&P 500 index in month $t ; S P_{t-i}$ is return on the $\mathrm{S} \& \mathrm{P} 500$ index in month $t-i ; B R E_{t}$ is return on Brent oil price index in month $t ; B R E_{t-1}$ is return on Brent oil price index in month $t-i ; \triangle E P U_{t}$ is change in the U.S. economic policy uncertainty index in month $t$; $\triangle E P U_{t-i}$ is change in the U.S. economic policy uncertainty index in month $t-i$.

\section{RESULTS AND DISCUSSION}

Table 1 shows the descriptive statistics of all the variables under study; the correlation between the variables are presented in Table 2 .

Table 1. Descriptive Statistics

\begin{tabular}{|c|c|c|c|}
\hline Variables & Mean & Std. Dev. & Obs. \\
\hline Bahrain & -1.1512 & 65.3240 & 169 \\
\hline Kuwait & 7.9739 & 481.1092 & 169 \\
\hline Oman & 5.7913 & 356.9300 & 169 \\
\hline Qatar & 26.0592 & 699.9756 & 169 \\
\hline Saudi Arabia & 10.4560 & 749.4658 & 169 \\
\hline UAE & 16.0114 & 276.7859 & 169 \\
\hline S\&P 500 & 10.6497 & 54.3082 & 169 \\
\hline Brent & 0.2212 & 6.5761 & 169 \\
\hline$\triangle E P U$ & 0.0533 & 23.2548 & 169 \\
\hline
\end{tabular}

Source: Authors' calculations

Table 2. Correlation Analysis

\begin{tabular}{|c|c|c|c|c|c|c|c|c|c|}
\hline & $\boldsymbol{\Delta E P U}$ & Bahrain & Kuwait & Oman & Qatar & $\begin{array}{c}\text { Saudi } \\
\text { Arabia }\end{array}$ & UAE & $\begin{array}{c}\text { S\&P } \\
\mathbf{5 0 0}\end{array}$ & Brent \\
\hline$\Delta E P U$ & 1.0000 & & & & & & & & \\
\hline Bahrain & -0.0664 & 1.0000 & & & & & & & \\
\hline Kuwait & -0.1058 & 0.7104 & 1.0000 & & & & & & \\
\hline Oman & -0.1764 & 0.5461 & 0.5956 & 1.0000 & & & & & \\
\hline Qatar & -0.1448 & 0.4407 & 0.4106 & 0.4916 & 1.0000 & & & & \\
\hline $\begin{array}{c}\text { Saudi } \\
\text { Arabia }\end{array}$ & -0.1091 & 0.3942 & 0.4080 & 0.4181 & 0.3332 & 1.0000 & & & \\
\hline UAE & -0.0436 & 0.5118 & 0.4694 & 0.4890 & 0.5367 & 0.4520 & 1.0000 & & \\
\hline S\&P 500 & -0.2214 & 0.2940 & 0.3329 & 0.3225 & 0.3117 & 0.2126 & 0.1699 & 1.0000 & \\
\hline Brent & -0.1419 & 0.3612 & -0.1058 & 0.4950 & 0.4055 & 0.2794 & 0.2189 & 0.3638 & 1.0000 \\
\hline
\end{tabular}

Source: Authors' calculations 
Based on Table 1, all analysed data showed a positive average return except Bahrain stock market, which demonstrated a negative average return of -1.1512 . The results of correlation analysis in Table 2 indicate a negative relationship between economic policy uncertainty in the U.S. and all the six GCC countries.

Table 3. Regression results of the impact of the economic policy uncertainty in the U.S. on the monthly returns of each GCC country

\begin{tabular}{|c|c|c|c|c|c|}
\hline Country & Coefficient & Std. Err. & $\boldsymbol{t}$ & Sig. & $\boldsymbol{R}^{\mathbf{2}}$ \\
\hline \multicolumn{2}{|c|}{ Panel: 2004:M7-2018:M8 $(n=170)$} & & & \\
\hline Bahrain & -0.1865 & 0.2163 & -0.86 & 0.3896 & 0.40 \\
\hline Kuwait & -2.1873 & 1.5874 & -1.38 & 0.1701 & 1.09 \\
\hline Oman & -2.7077 & 1.1657 & -2.32 & 0.0214 & 3.08 \\
\hline Qatar & -4.3573 & 2.2994 & -1.89 & 0.0598 & 1.96 \\
\hline Saudi Arabia & -3.5142 & 2.4719 & -1.42 & 0.1570 & 1.17 \\
\hline UAE & -0.5174 & 0.9189 & -0.56 & 0.5742 & 0.15 \\
\hline
\end{tabular}

Source: Authors' calculations

As reported in Table 3, monthly returns on each GCC stock market are regressed on economic policy uncertainty in the U.S. using time-series OLS regression; the results in Table 3 present a statistical insignificant negative correlation for all returns on the GCC markets except Oman, which is statistically significant with a negative coefficient. Thus, economic policy uncertainty in the U.S. affects return on the Oman stock market negatively.

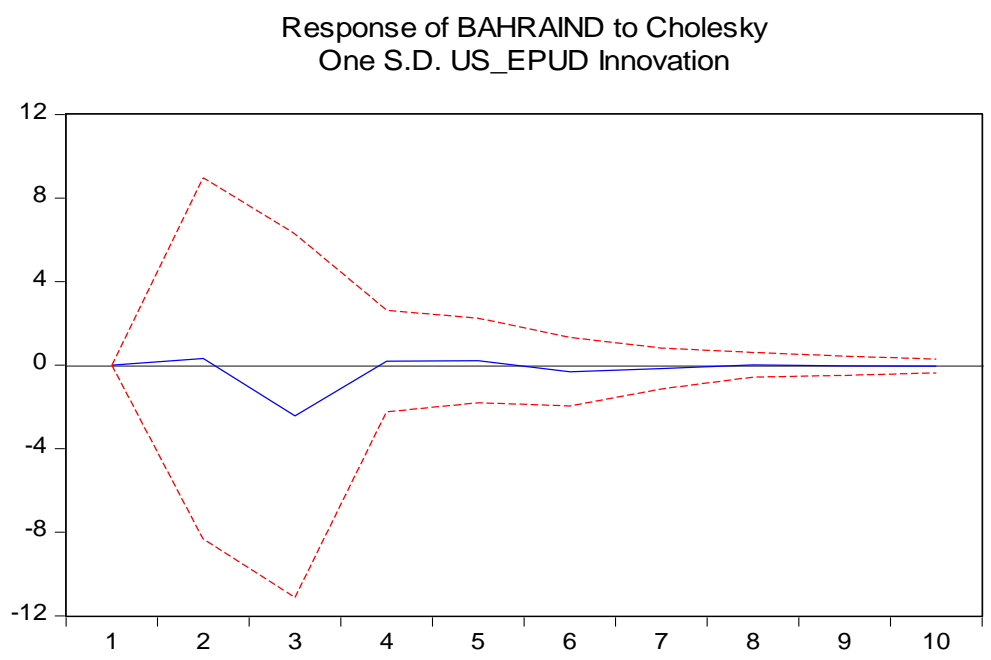

Fig. 1. The impulse response functions of the returns on Bahrain stock market to changes in the U.S. economic policy uncertainty (2004:M7 - 2018:M8) 


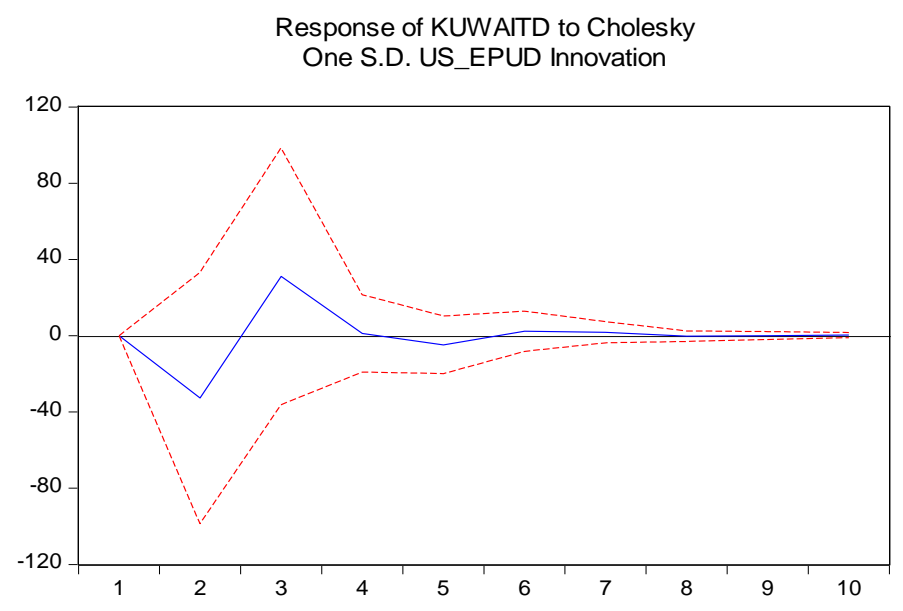

Fig. 2. The impulse response functions of the returns on Kuwait stock market to changes in the U.S. economic policy uncertainty (2004:M7 - 2018:M8)

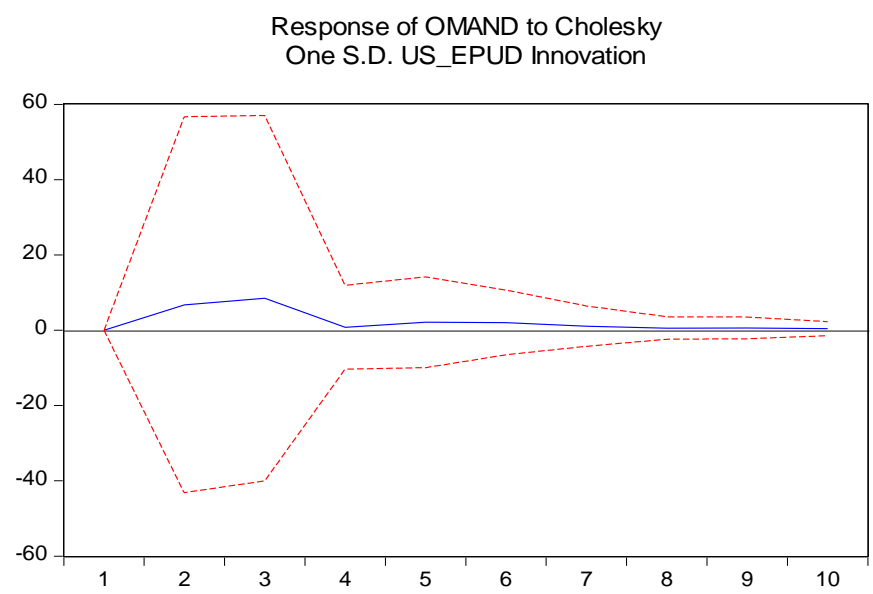

Fig. 3. The impulse response functions of the returns on Oman stock market to changes in the U.S. economic policy uncertainty (2004:M7 - 2018:M8)

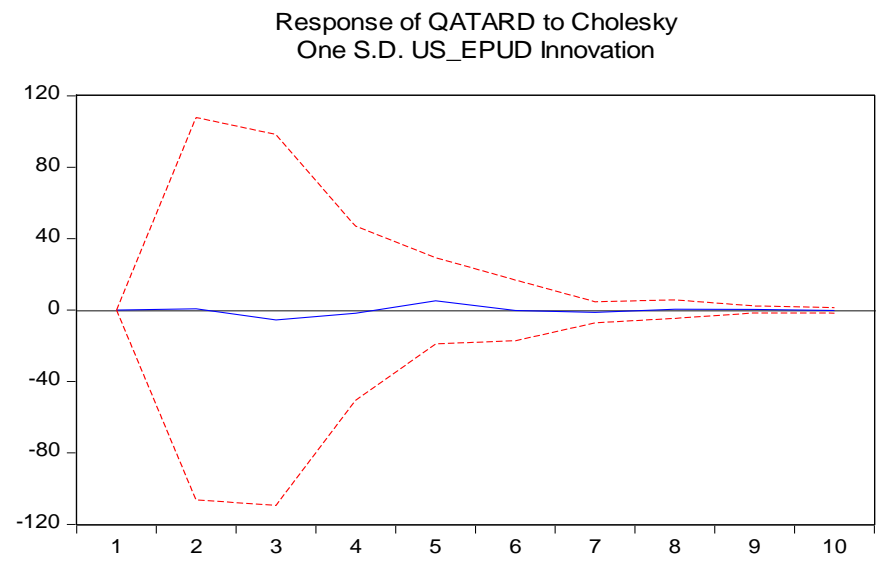

Fig. 4. The impulse response functions of the returns on Qatar stock market to changes in the U.S. economic policy uncertainty (2004:M7 - 2018:M8) 


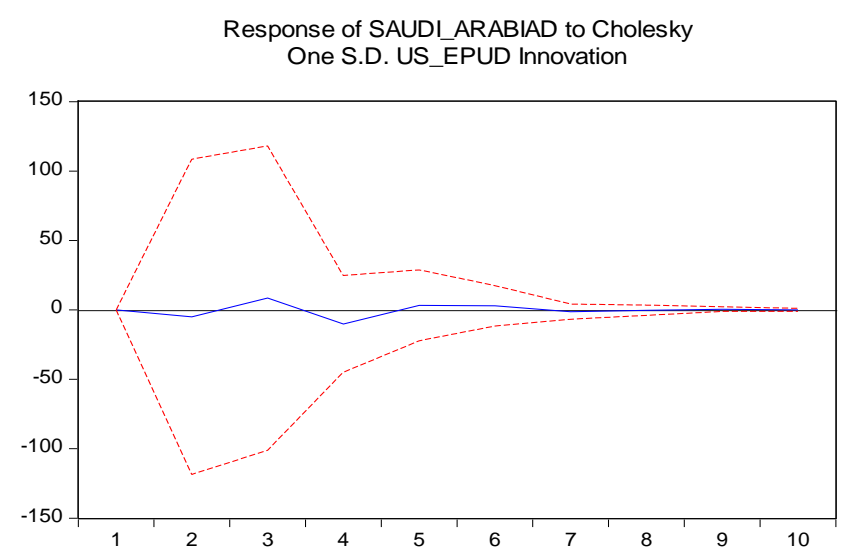

Fig. 5. The impulse response functions of the returns on Saudi Arabia stock market to changes in the U.S. economic policy uncertainty (2004:M7 - 2018:M8)

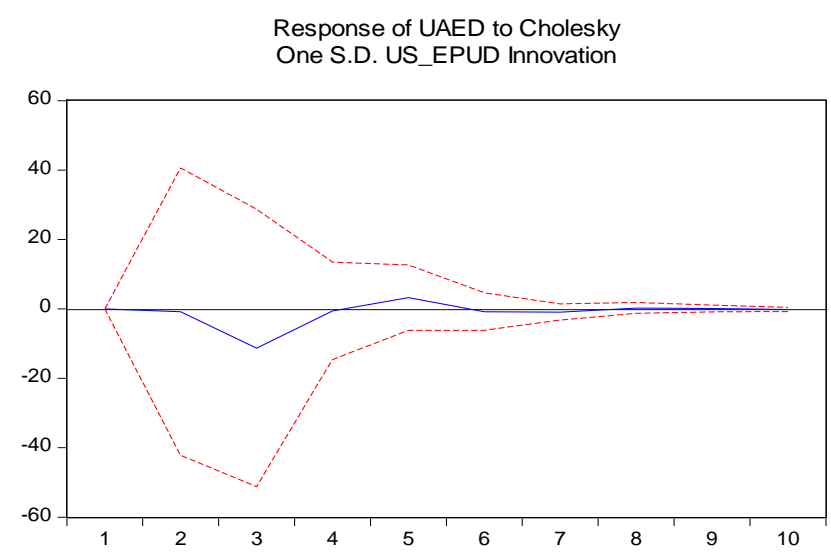

Fig. 6. The impulse response functions of the returns on Saudi Arabia stock market to changes in the U.S. economic policy uncertainty (2004:M7 - 2018:M8)

Table 4. Regression results with control variables for the impact of the economic policy uncertainty in the U.S. on the monthly returns of each GGC country

\begin{tabular}{|c|c|c|c|c|c|}
\hline Country & Coefficient & Std. Err. & $t$ & Sig. & $R^{2}$ \\
\hline \multicolumn{6}{|c|}{ Panel: 2004:M7-2018:M8 $(n=170)$} \\
\hline Bahrain & 0.0415 & 0.2055 & 0.20 & 0.8401 & \multirow{3}{*}{15.71} \\
\hline S\&P 500 & 0.2130 & 0.0917 & 2.32 & 0.0215 & \\
\hline Brent & 2.9477 & 0.7611 & 3.87 & 0.0002 & \\
\hline Kuwait & -0.3500 & 1.4921 & -0.23 & 0.8148 & \multirow{3}{*}{18.10} \\
\hline S\&P 500 & 1.9283 & 0.6660 & 2.89 & 0.0043 & \\
\hline Brent & 21.0055 & 5.5255 & 3.80 & 0.0002 & \\
\hline Oman & -1.2886 & 1.0421 & -1.24 & 0.2180 & \multirow{3}{*}{27.41} \\
\hline S\&P 500 & 0.9347 & 0.4652 & 2.01 & 0.0461 & \\
\hline Brent & 23.3631 & 3.8592 & 6.05 & 0.0000 & \\
\hline Qatar & -1.7660 & 2.1474 & -0.82 & 0.4120 & \multirow{3}{*}{19.87} \\
\hline S\&P 500 & 2.2679 & 0.9586 & 2.36 & 0.0191 & \\
\hline Brent & 35.4394 & 7.9521 & 4.46 & 0.0000 & \\
\hline
\end{tabular}




\begin{tabular}{|c|c|c|c|c|c|}
\hline Country & Coefficient & Std. Err. & $\boldsymbol{t}$ & Sig. & \multirow{2}{*}{$\boldsymbol{R}^{\mathbf{2}}$} \\
\hline Saudi Arabia & -1.6486 & 2.4443 & -0.67 & 0.5009 & \multirow{2}{*}{9.44} \\
\hline S\&P 500 & 1.5788 & 1.0911 & 1.45 & 0.1498 & \\
\hline Brent & 26.2104 & 9.0515 & 2.89 & 0.0043 & \multirow{2}{*}{5.64} \\
\hline UAE & 0.0805 & 0.9214 & 0.09 & 0.9304 & \\
\hline S\&P 500 & 0.5692 & 0.4113 & 1.38 & 0.1683 & \\
\hline Brent & 7.5871 & 3.4122 & 2.22 & 0.0275 & \\
\hline
\end{tabular}

Source: Authors' calculations

In order to control for the effect of U.S. stock market and oil price, monthly returns on each GCC stock market is regressed on economic policy uncertainty in the U.S. (EPU), return on the U.S. stock markets (S\&P500) and oil price (Brent). The results of full sample data from 2004:7 to 2018:8 show that all the coefficients of the GCC markets are statistically insignificant, i.e., economic policy uncertainty in the U.S. has no impact on all the six GCC countries.

Table 5. Granger Causality Wald Tests

\begin{tabular}{|c|c|c|c|c|}
\hline Equation & Excluded & Chi - sq & df & Prob. \\
\hline Bahrain & S\&P 500 & 2.15 & 2 & 0.301 \\
\hline Bahrain & Brent & 2.40 & 2 & 0.342 \\
\hline Bahrain & $\Delta E P U$ & 0.10 & 2 & 0.952 \\
\hline Bahrain & ALL & 7.09 & 6 & 0.312 \\
\hline S\&P 500 & Bahrain & 2.49 & 2 & 0.287 \\
\hline S\&P 500 & Brent & 2.00 & 2 & 0.368 \\
\hline S\&P 500 & $\Delta E P U$ & 2.17 & 2 & 0.337 \\
\hline S\&P 500 & ALL & 8.35 & 6 & 0.214 \\
\hline Brent & Bahrain & 4.84 & 2 & 0.009 \\
\hline Brent & S\&P 500 & 0.44 & 2 & 0.802 \\
\hline Brent & $\Delta E P U$ & 2.67 & 2 & 0.263 \\
\hline Brent & ALL & 7.69 & 6 & 0.262 \\
\hline$\Delta E P U$ & Bahrain & 2.33 & 2 & 0.312 \\
\hline$\Delta E P U$ & S\&P 500 & 10.19 & 2 & 0.006 \\
\hline$\Delta E P U$ & Brent & 0.20 & 2 & 0.906 \\
\hline$\Delta E P U$ & ALL & 13.68 & 6 & 0.033 \\
\hline
\end{tabular}

Source: Authors' calculations

Table 6. Granger Causality Wald Tests

\begin{tabular}{|c|c|c|c|c|}
\hline Equation & Excluded & Chi - sq & df & Prob. \\
\hline Kuwait & S\&P 500 & 0.39 & 2 & 0.824 \\
\hline Kuwait & Brent & 7.46 & 2 & 0.024 \\
\hline Kuwait & $\Delta E P U$ & 3.08 & 2 & 0.215 \\
\hline Kuwait & ALL & 11.75 & 6 & 0.113 \\
\hline S\&P 500 & Kuwait & 6.20 & 2 & 0.045 \\
\hline S\&P 500 & Brent & 1.68 & 2 & 0.432 \\
\hline S\&P 500 & $\Delta E P U$ & 2.21 & 2 & 0.313 \\
\hline S\&P 500 & ALL & 12.19 & 6 & 0.067 \\
\hline Brent & Kuwait & 3.56 & 2 & 0.169 \\
\hline Brent & S\&P 500 & 0.28 & 2 & 0.868 \\
\hline
\end{tabular}




\begin{tabular}{|c|c|c|c|c|}
\hline Equation & Excluded & Chi - sq & df & Prob. \\
\hline Brent & $\Delta E P U$ & 2.55 & 2 & 0.279 \\
\hline Brent & ALL & 6.39 & 6 & 0.381 \\
\hline$\Delta E P U$ & Kuwait & 0.30 & 2 & 0.861 \\
\hline$\Delta E P U$ & S\&P 500 & 863 & 2 & 0.914 \\
\hline$\Delta E P U$ & Brent & 0.18 & 2 & 0.013 \\
\hline$\Delta E P U$ & ALL & 11.50 & 6 & 0.074 \\
\hline
\end{tabular}

Source: Authors' calculations

Table 7. Granger Causality Wald Tests

\begin{tabular}{|c|c|c|c|c|}
\hline Equation & Excluded & Chi - sq & df & Prob. \\
\hline Oman & S\&P 500 & 0.32 & 2 & 0.853 \\
\hline Oman & Brent & 0.38 & 2 & 0.828 \\
\hline Oman & $\Delta E P U$ & 0.19 & 2 & 0.909 \\
\hline Oman & ALL & 0.88 & 6 & 0.990 \\
\hline S\&P 500 & Oman & 2.65 & 2 & 0.265 \\
\hline S\&P 500 & Brent & 2.34 & 2 & 0.310 \\
\hline S\&P 500 & $\Delta E P U$ & 1.57 & 2 & 0.455 \\
\hline S\&P 500 & ALL & 8.51 & 6 & 0.203 \\
\hline Brent & Oman & 14.34 & 2 & 0.000 \\
\hline Brent & S\&P 500 & 0.46 & 2 & 0.795 \\
\hline Brent & $\Delta E P U$ & 2.16 & 2 & 0.340 \\
\hline Brent & ALL & 17.36 & 6 & 0.008 \\
\hline$\Delta E P U$ & Oman & 0.36 & 2 & 0.836 \\
\hline$\Delta E P U$ & S\&P 500 & 8.95 & 2 & 0.011 \\
\hline$\Delta E P U$ & Brent & 0.19 & 2 & 0.909 \\
\hline$\Delta E P U$ & ALL & 11.57 & 6 & 0.072 \\
\hline
\end{tabular}

Source: Authors' calculations

Table 8. Granger Causality Wald Tests

\begin{tabular}{|c|c|c|c|c|}
\hline Equation & Excluded & Chi - sq & df & Prob. \\
\hline Qatar & S\&P 500 & 0.03 & 2 & 0.985 \\
\hline Qatar & Brent & 4.76 & 2 & 0.093 \\
\hline Qatar & $\Delta E P U$ & 0.00 & 2 & 0.999 \\
\hline Qatar & ALL & 5.29 & 6 & 0.507 \\
\hline S\&P 500 & Qatar & 9.09 & 2 & 0.011 \\
\hline S\&P 500 & Brent & 6.92 & 2 & 0.031 \\
\hline S\&P 500 & $\Delta E P U$ & 1.61 & 2 & 0.446 \\
\hline S\&P 500 & ALL & 15.18 & 6 & 0.019 \\
\hline Brent & Qatar & 0.28 & 2 & 0.867 \\
\hline Brent & S\&P 500 & 0.18 & 2 & 0.912 \\
\hline Brent & $\Delta E P U$ & 2.17 & 2 & 0.338 \\
\hline Brent & ALL & 3.06 & 6 & 0.801 \\
\hline$\Delta E P U$ & Qatar & 1.19 & 2 & 0.552 \\
\hline$\Delta E P U$ & S\&P 500 & 8.89 & 2 & 0.986 \\
\hline$\Delta E P U$ & Brent & 0.03 & 2 & 0.012 \\
\hline$\Delta E P U$ & ALL & 12.45 & 6 & 0.053 \\
\hline
\end{tabular}

Source: Authors' calculations 
Table 9. Granger Causality Wald Tests

\begin{tabular}{|c|c|c|c|c|}
\hline Equation & Excluded & Chi - sq & df & Prob. \\
\hline Saudi Arabia & S\&P 500 & 0.87 & 2 & 0.645 \\
\hline Saudi Arabia & Brent & 3.07 & 2 & 0.215 \\
\hline Saudi Arabia & $\Delta E P U$ & 0.03 & 2 & 0.983 \\
\hline Saudi Arabia & ALL & 4.30 & 6 & 0.636 \\
\hline S\&P 500 & Saudi Arabia & 3.46 & 2 & 0.178 \\
\hline S\&P 500 & Brent & 3.78 & 2 & 0.151 \\
\hline S\&P 500 & $\Delta E P U$ & 1.55 & 2 & 0.460 \\
\hline S\&P 500 & ALL & 9.35 & 6 & 0.155 \\
\hline Brent & Saudi Arabia & 1.09 & 2 & 0.579 \\
\hline Brent & S\&P 500 & 0.15 & 2 & 0.929 \\
\hline Brent & $\Delta E P U$ & 2.26 & 2 & 0.323 \\
\hline Brent & ALL & 3.88 & 6 & 0.692 \\
\hline$\Delta E P U$ & Saudi Arabia & 0.75 & 2 & 0.687 \\
\hline$\Delta E P U$ & S\&P 500 & 9.97 & 2 & 0.007 \\
\hline$\Delta E P U$ & Brent & 0.38 & 2 & 0.825 \\
\hline$\Delta E P U$ & ALL & 11.99 & 6 & 0.062 \\
\hline
\end{tabular}

Source: Authors' calculations

Table 10. Granger Causality Wald Tests

\begin{tabular}{|c|c|c|c|c|}
\hline Equation & Excluded & Chi - sq & df & Prob. \\
\hline UAE & S\&P 500 & 0.04 & 2 & 0.981 \\
\hline UAE & Brent & 5.64 & 2 & 0.059 \\
\hline UAE & $\Delta E P U$ & 0.22 & 2 & 0.897 \\
\hline UAE & ALL & 7.79 & 6 & 0.254 \\
\hline S\&P 500 & UAE & 1.80 & 2 & 0.406 \\
\hline S\&P 500 & Brent & 3.67 & 2 & 0.160 \\
\hline S\&P 500 & $\Delta E P U$ & 2.12 & 2 & 0.347 \\
\hline S\&P 500 & ALL & 7.63 & 6 & 0.266 \\
\hline Brent & UAE & 3.89 & 2 & 0.143 \\
\hline Brent & S\&P 500 & 0.24 & 2 & 0.889 \\
\hline Brent & $\Delta E P U$ & 2.17 & 2 & 0.337 \\
\hline Brent & ALL & 6.73 & 6 & 0.347 \\
\hline$\Delta E P U$ & UAE & 0.79 & 2 & 0.674 \\
\hline$\Delta E P U$ & S\&P 500 & 9.16 & 2 & 0.010 \\
\hline$\Delta E P U$ & Brent & 0.15 & 2 & 0.927 \\
\hline$\Delta E P U$ & ALL & 12.02 & 6 & 0.061 \\
\hline
\end{tabular}

Source: Authors' calculations

The results of VAR analysis indicate that the returns on all the six GCC markets do not respond to a shock in economic policy uncertainty in the U.S. (Figs. 1-5). The results of Granger Causality tests in Tables 5-9 reveal that economic policy uncertainty in the U.S. does not cause returns of all the six GCC markets. 


\section{CONCLUSION}

Global spillovers can cause serious shocks in wide open economies that have intensive trade with some of the biggest economies in the world. Financial crisis of 2007-2008 had terrific consequences to many global economies, especially to those that had intensive trade with the U.S. GCC countries stand for a long time economic partner of the U.S. and they were also affected by economic shocks that started in the U.S. This study has examined if the changes in economic policy uncertainty in the U.S. can explain the returns on stock markets of Bahrain, Kuwait, Oman, Qatar, Saudi Arabia and the United Arab Emirates.

This study has also investigated how the stock market returns of the six countries respond to the changes in economic policy uncertainty in the U.S. The results have shown that changes in economic policy uncertainty in the U.S. are not significantly linked with the returns on all the stock markets except Oman stock market, which demonstrates a statistical significant negative relationship with the changes in economic policy uncertainty in the U.S. Controlling for the effects of the U.S stock market and oil price, returns on all the six GCC markets including Oman show insignificant coefficients.

The returns on all the stock markets do not respond to the changes in economic policy uncertainty. The results of Granger causality tests show that the changes in economic policy uncertainty in the U.S. do not cause the returns of all the six GCC stock markets.

The results propose that the GCC stock market performance is not related to the changes in economic policy uncertainty in the U.S. This implies that market participants in the GCC markets do not perceive economic policy circumstances in the U.S.

\section{REFERENCES}

Anthony, J. D. (1999). US-GCC Trade and Investment Relations, US-GCC Corporate Cooperation Committee, Washington, DC.

Basu, S., \& Bundick, B. (2014). Uncertainty Shocks in a Model of Effective Demand. NBER Working paper 18420. Retrieved from https://www.nber.org/papers/w18420.pdf

Bayoumi, T., \& Swiston, A. (2007). Foreign Entanglements: Estimating the Source and the Size of Spillover Across Industrial Countries. IMF Working Paper WP/07/128, June.

Becker, K. G., Finnerty, J. E., \& Friedman, J. (1995). Economic News and Equity Market Linkages between the US and UK. Journal of Banking \& Finance, 19(7), 1191-1210. https://doi.org/10.1016/03784266(94)00079-I

Beirne, J., Caporale, G. M., Schulze - Ghattas, M., \& Spagnolo, N. (2010). Global and Regional Spillovers in Emerging Stock Markets: A Multivariate GARCH - in - Mean Analysis. Emerging Markets Review, 11(3), 250-260. https://doi.org/10.1016/j.ememar.2010.05.002

Bernanke, B. S. (1983). Irreversibility, Uncertainty and Cyclical Investment. Quarterly Journal of Economics, 98(1), 85-106. https://doi.org/10.2307/1885568

Boako, G., \& Alagidede, P. (2018). African Stock Markets in the Midst of the Global Financial Crisis: Recoupling or Decoupling? Research in International Business and Finance, 46, 166-180. https://doi.org/10.1016/j.ribaf.2018.02.001

Born, B., \& Pfeifer, J. (2014). Policy Risk and the Business Cycle. Journal of Monetary Economics, 68, 6885. https://doi.org/10.1016/j.jmoneco.2014.07.012

Ehrmann, M., \& Fratzscher, M. (2004). Equal Size, Equal Role? Interest Rate Interdependence between the Euro Area and the United States. The Economic Journal, 115(506), 928-948. https://doi.org/10.1111/j.1468-0297.2005.01025.x 
Ehrmann, M., \& Fratzscher, M. (2009). Global Financial Transmission of Monetary Policy Shocks. Oxford Bulletin of Economics and Statistics, 71(6), 739-759. https://doi.org/10.1111/j.1468-0084.2009.00561.x

European Commission. (2018). European Union, Trade in Goods with GCC. Retrieved from trade.ec.europa.eu/doclib/docs/2006/September/tradeec_113482.pdf

Fadejeva, L., Feldkircher, M., \& Reininger, T. (2017). International Spillovers from Euro Area and US Credit and Demand Shocks: A Focus on Emerging Europe. Journal of International Money and Finance, 70, 125. https://doi.org/10.1016/j.jimonfin.2016.08.001

Fernandez - Villaverde, J., Guerron - Quintana, P., Kuester, K., \& Rubio -Ramirez, K. (2015). Fiscal Volatility Shocks and Economic Activity. American Economic Review, 105(11), 3352-3384. https://doi.org/10.1257/aer.20121236

Fratzscher, M., Lo Duca, M., \& Straub, R. (2018). On the International Spillovers of US Quantitative Easing. The Economic Journal, 128(608), 330-377. https://doi.org/10.1111/ecoj.12435

Friedman, M. (1968). The Role of Monetary Policy', American Economic Review, 58(1), 1-17. Retrieved from http://itech.fgcu.edu/faculty/bhobbs/Milton\%20Friedman\%20The\%20Role\%20of\%20Monetary\%20Polic y.pdf

Gilchrist, S., Sim, J. W., \& Zakrajšek, E. (2014). Uncertainty, Financial Frictions and Investment Dynamics. NBER Working Paper 20038. Retrieved from https://www.nber.org/papers/w20038.pdf

Goldberg, L. S., \& Leonard, D. (2003). What Moves Sovereign Bond Markets? The Effects of Economic News on US and German Yields. Current Issues in Economics and Finance, 9(9), 1-7. Retrieved from https://www.newyorkfed.org/medialibrary/media/research/current_issues/ci9-9.pdf

Hamao, Y., Masulis, R.W., \& Ng, V. (1990). Correlations in Price Changes and Volatility Across International Stock Markets. Review of Financial Studies, 3(2), 281-307. https://doi.org/10.1093/rfs/3.2.281

Hassett, K. A., \& Metcalf, G. E. (1999). Investment with Uncertain Tax Policy: Does Random Tax Policy Discourage Investment? The Economic Journal, 109(457), 372-393. https://doi.org/10.1111/1468$\underline{0297.00453}$

Higgs, R. (1997). Regime Uncertainty: Why the Great Depression Lasted So Long and Why Prosperity Resumed After the War. The Independent Review, 1(4), 561-590. Retrieved from https://www.jstor.org/stable/24560785

Johansson, A. C., \& Ljungwall, C. (2009). Spillover Effects among the Greater China Stock Markets. World Development, 37(4), 839-851. https://doi.org/10.1016/j.worlddev.2008.07.015

Kim, S. J., Salem, L., \& Wu, E. (2015). The Role of Macroeconomic News in Sovereign CDS Markets: Domestic and Spillover News Effects from the U.S, the Eurozone and China. Journal of Financial Stability, 18, 208-224. https://doi.org/10.1016/j.jfs.2015.04.008

King, M., Sentana, E., \& Wadhwani, S. (1994). Volatility and Links between National Stock Markets. Econometrica, 62(4), 901-933. https://doi.org/10.2307/2951737

Leduc, S., \& Liu, Z. (2015). Uncertainty Shocks are Aggregate Demand Shocks. Federal Reserve Bank of San Francisco Working Paper 2012-10. Retrieved from https://www.frbsf.org/economic-research/files/wp1210bk.pdf

Lin, W., Engle, R. F., \& Ito, T. (1994). Do Bulls and Bears Move Across Borders? International Transmission of Stock Returns and Volatility. Review of Financial Studies, 7(3), 507-538. https://doi.org/10.1093/rfs/7.3.507

Marquez, M. A., Ramajo, J., \& Hewings, G. J. D. (2015). Regional Growth and Spatial Spillovers: Evidence from a SPVAR for the Spanish regions. Regional Science, 94(1), 1-18. https://doi.org/10.1111/pirs. 12102

Marquez - Ramos, L. (2016). Port Facilities, Regional Spillovers and Exports: Empirical Evidence from Spain', Regional Science, 95(2), 329-351. https://doi.org/10.1111/pirs.12127

Ouyang, P., \& Fu, S. (2012). Economic growth, local industrial development and Inter-Regional Spillovers from Foreign Direct Investments: Evidence from China. China Economic Review, 23(2), 445-460. https://doi.org/10.1016/j.chieco.2012.03.005

Panousi, V., \& Papanikolaou, D. (2012). Investment, Idiosyncratic Risk and Ownership. Journal of Finance, 67(3), 1113-1148. https://doi.org/10.1111/j.1540-6261.2012.01743.x

Pastor, L., \& Veronesi, P. (2012). Uncertainty about Government Policy and Stock Market Prices. Journal of Finance, 67(4), 1219-1264. https://doi.org/10.1111/j.1540-6261.2012.01746.x

Pastor, L., \& Veronesi, P. (2013). Political Uncertainty and Risk Premia. Journal of Financial Economics, 110(3), 520-545. https://doi.org/10.1016/j.jfineco.2013.08.007

Rodrik, D. (1991). Policy Uncertainty and Private Investment. Journal of Development Economics, 36(2), 229242. https://doi.org/10.1016/0304-3878(91)90034-S

Sugimoto, K., Matsuki, T., \& Yoshida, Y. (2014). The Global Financial Crisis: An Analysis of Spillover Effects on African Stock Markets. Emerging Markets Review, 21, 201-233. https://doi.org/10.1016/j.ememar.2014.09.004

Sum, V. (2012). Economic Policy Uncertainty and Stock Market Performance: Evidence from the European Union, Croatia, Norway, Russia, Switzerland, Turkey and Ukraine, Journal of Money, Investment and Banking, 25, 99-104. https://doi.org/10.2139/ssrn.2094175 
World Bank. (2010). Economic Integration in the GCC. Retrieved from https://siteresources.worldbank.org/INTMENA/Resources/GCCStudyweb.pdf.

Zhou, X., Zhang, W., \& Zhang, J. (2012). Volatility Spillovers between the Chines and World Equity Markets. Pacific - Basin Finance Journal, 20(2), 247-270. https://doi.org/10.1016/j.pacfin.2011.08.002

\section{AUTHORS' SHORT BIOGRAPHIES}

Abdullah Saeed S Alqahtani, photograph and biography not available at the time of publication.

Hongbing Ouyang, photograph and biography not available at the time of publication.

Adam Ali, photograph and biography not available at the time of publication. 